\title{
Analyzing the institutional and regulatory framework for operationalizing the blue economy in Bangladesh: Lessons from Australia
}

\author{
Md. Mizanur Rahman ( $\square$ mizan_peroj@yahoo.com ) \\ ICT Division, Government of the People's Republic of Bangladesh
}

\section{Research Article}

Keywords: Coastal and Marine Resource, Potential, Jurisdictional Overlapping, Conflict of Interests, Marine Governance, Artisanal Fishers

Posted Date: December 15th, 2021

DOI: https://doi.org/10.21203/rs.3.rs-1163138/v2

License: (c) (i) This work is licensed under a Creative Commons Attribution 4.0 International License. Read Full License 


\section{Abstract}

This study's overarching objective was to assess the suitability and applicability of the existing legal and institutional framework for managing the coastal and marine resources in Bangladesh. Besides, the legal and institutional arrangement of Australia was examined to adopt the best practices for Bangladesh. The glimpse of potential coastal and marine resources of Bangladesh was assessed to have an idea of the untapped resources' dimensions. Together with, the fundamental challenges faced by the artisanal and small-scale fishers in Bangladesh were critically scrutinized. The empirical data collection followed a multi-approach like mini-symposium, consultation workshops, focus group discussions, case studies, visiting, personal, and key informant interviews. The study revealed that the vast provisioning, regulating, and cultural ecosystem services of the Bay of Bengal, including its coast and mangrove, is mostly unexplored. The regulatory framework in Bangladesh is characterized by jurisdictional overlapping followed by the conflict of interests among the public institutes, which originated from the aged and fragmented laws and ambiguous business allocation; consequently, the artisanal and small-scale fishers suffer a lot. On the flip side, despite some limitations, Australia established sectoral governance enacting strong legislative measures. The local government and community's right in resource management locally has been institutionalized in Australia, which remains fuzzy in Bangladesh. Taking lessons from Australia, Bangladesh can enact new sectoral laws followed by business reallocation for the line ministries. The study will help policymakers identify the bottlenecks rooted in Bangladesh's existing regulatory and institutional framework.

\section{Introduction}

Bangladesh is located in the north-east corner of the Bay of Bengal and blessed with living and non-living resources (FAO, 2014). The living resources of the Bay of Bengal comprised of fisheries, pearls, corals, mangroves, planktons, and seaweeds, and other ecosystem services (Ahmed and Glaser, 2016; Islam and Shamsuddoha, 2018). The Sundarbans mangrove also supplies essential ecosystem services like fish, crabs, turtles, shrimp, honey, medicinal plants, Nypa palm leaf, wax, wood, white mangrove date palm, and fodder. Extraction, exploration, management, and conservation of both living and non-living resources of the Bay can contribute a lot to Bangladesh's economy (Hasan et al., 2018). The Bay of Bengal can offer considerable opportunities to resolve the challenges originating from the climate changes in the coastal areas (Giménez et al., 2014). Bangladesh confronts both incremental local (Rahman, 2009, Rahman et al., 2009; Rahman and Vacik, 2010) and climatic stressors (Rahman 2020; Rahman et al. 2021) to protect its natural resources. On the other hand, sustainable resource management may generate decent works and bring a tangible change in the people residing in the coastal zones and across the country (Ahmed and Rahman 2019). The potential of the marine and coastal resources has not been identified so far. Hence, the study aimed to assess the unexplored potential marine and coastal resources that can be utilized for ensuring food and health security, poverty reduction, employment generation, and finally, the economic growth of Bangladesh. 
Several studies found that the implementation level's institutional mechanisms are not adequately functional to flourish coastal and marine fisheries in Bangladesh (Shamsuzzaman and Islam, 2018; Shamsuzzaman et al., 2017a, b; Islam, 2012). Few old laws, especially inland laws, provide legal frameworks for fisheries management, which are not appropriately enforced for multiple reasons. The existing legal framework has led "sector-by-sector" or "use-by-use" management practices. Diversely, the institutional mechanism, marine governance, stakeholder engagement, and coordination among different players are not clearly defined (Shamsuzzaman et al., 2017a; Rahman et al., 2020; Rahman and Alam 2020, Rahman 2021 a, b, c, d). Marine growth unquestionably depends on the connectivity among the terrestrial, freshwater, and marine realms. Therefore, a comprehensive study on coastal and marine resource management regulatory regimes in Bangladesh, considering both legal and institutional arrangements, has become indispensable. Thus, the study aims at analyzing the legal and institutional frameworks embedded with blue growth. This analysis will help in the identification of the knowledge gap and existing challenges. The study will immensely contribute to pinpointing the narrow and broad interfaces, constraints, and diffused connections among institutions from top to bottom.

The artisanal and small-scale fisheries face significant challenges that emerge from a policy implementation gap and weak law enforcement (Billah et al., 2018). The proportion of artisanal and small-scale fishers show a declining trend decreasing at an alarming rate due to lack of an integrated and holistic regulatory and institutional framework, which propagate a distorted market chain, climate vulnerabilities, and hegemony of the commercial fishers (Alam et al., 2021; Akhtar et al., 2017, Rahman $2021 \mathrm{a}, \mathrm{e}, \mathrm{f})$. This vulnerable group is becoming a "left behind the group" by losing their income. The study also examined the fishers' challenges, notably artisanal and small-scale, to make policy interventions.

Australia, a marine state having the third-largest maritime jurisdiction in the world, adopted comprehensive measures for maximizing the use of marine resources for narrowing down the significant development gaps, through promoting scientific, technological, and other innovations, and establishing necessary mechanisms for regional cooperation among the neighboring countries (Mohanty et al., 2015). In the Rio+20 Conference, Australia came up with a clear vision to manage marine resources sustainably with ambitious goals (Campbell et al., 2013). Substantial efforts were made in the 2000s for promoting marine science in the country, which ultimately culminated in the form of the "National Marine Science Plan 2015-2025," identifying several priority areas. Australia launched the Oceans Policy in 1998 to coordinate marine activities. The policy aimed to create an effective and efficient ocean management regime and establish the framework for integrated and ecosystem-based planning and management for the marine jurisdictions (Akwilapo, 2007). Australia has also developed institutional and regulatory frameworks separately for the State, Territory, and Commonwealth Government. The Oceans Policy is treated as a high-level "umbrella" policy integrating and coordinating existing mechanisms (Akwilapo, 2007). 
Australia, a federation, still faces many challenges like jurisdictional overlapping and the conflicts in establishing the indigenous peoples' rights (Boon and Baxter, 2020; Bolton et al., 2020; Bray et al., 2019; Yin and Techera, 2019). At the initial stage, it encountered the same problems that Bangladesh faces now. Through a trial-and-error process, Australia established sectoral governance and came up with strong legislative measures. Therefore, Bangladesh can learn from Australia to reform regulatory and institutional frameworks to avoid repeated errors and trials. However, Bangladesh cannot be compared with Australia regarding geographical location, marine resources, and economic development. Therefore, the study strived to identify Australia's legal and institutional framework's positive aspects, which will help Bangladesh in enacting sectoral laws and reallocation of business for the government functionaries.

\section{Initiatives for unlocking the potentials of marine resources in Bangladesh}

Bangladesh has taken several initiatives towards fortifying the institutional structures for harnessing the full utilization of marine-based potential resources eyeing on SDG 14 (Table 1).

Table 1: List of the institutional initiatives for trapping coastal and marine resources in Bangladesh (Bdgov, 2020) 


\begin{tabular}{|c|c|}
\hline Institution & Initiatives \\
\hline MOFA & $\begin{array}{l}\text { Established a Maritime Affairs Unit (MAU) to prepare position papers to fix } \\
\text { the maritime boundary with the neighboring countries }\end{array}$ \\
\hline MOEF & Appointed a focal point of the blue economy \\
\hline MOS & $\begin{array}{l}\text { Prepared a long and midterm strategic action plan for the extraction of } \\
\text { marine resources }\end{array}$ \\
\hline MPEMR & $\begin{array}{l}\text { Structured a "Blue Economy Cell" to explore and extract mineral resources } \\
\text { from the "Bay of Bengal }\end{array}$ \\
\hline MOFL & Shaped a "Blue Economy Corner" to explore marine fisheries \\
\hline Moedu/AFD & $\begin{array}{l}\text { Established } B S M R M U \text { that has started its voyage with the maxim of } \\
\text { providing skilled and knowledgeable human resources soon }\end{array}$ \\
\hline MOST & $\begin{array}{l}\text { Established } B O R I \text { that has started walking and limping with the } \\
\text { underdeveloped legs }\end{array}$ \\
\hline GED & Identified key the ministries/divisions in achieving SDG-14 \\
\hline$M P E M R$ & $\begin{array}{l}\text { Established } S R E D A \text { to explore alternative sources of energy (renewable), } \\
\text { including blue energy }\end{array}$ \\
\hline$P M O$ & $\begin{array}{l}\text { Formed a national coordination committee of marine resource extraction } \\
\text { and management in } 2014 \text { through a gazette notification and appointing the } \\
\text { "Principal Secretary to the PMO as the chief coordinator to monitor the } \\
\text { action plans taken by different ministries and divisions }\end{array}$ \\
\hline
\end{tabular}

$M O F A=$ Ministry of Foreign Affairs; $M O F L=$ Ministry of Fisheries and Livestock; $M O S=$ Ministry of Shipping; $M P E M R=$ Ministry of Power, Energy and Minerals; $M O E F=$ Ministry of Environment, Forest and Climate Change; GED=General Economic Division; Moedu=Ministry of Education; $A F D=$ Armed Forces Division; MOST= Ministry of Science and Technology; $P M O=$ Prime Minister's Office; $B O R I=$ Bangladesh Oceanographic Research Institute; $S R E D A=$ Sustainable and Renewable Energy Development Authority; BSMRMU=Bangabandhu Sheikh Mujibur Rahman Maritime University

\section{Methodology}

The study collected both primary and secondary data for the period from November 2018 to April 2020. Secondary data regarding the relevant Acts, Ordinances, and Rules relating to marine resource management and sustainability of Bangladesh and Australia were analyzed to develop background information.

\subsection{Primary data collection}

\subsubsection{Bangladesh}


The primary data collection in Bangladesh followed a mixed approach, including workshops, case studies, personal and key informant interviews (KKIs). A national consultation workshop was held in Dhaka, incorporating ministries, research, training, and educational institutes, and civil society. The participants were divided into two thematic groups: legal and institutional. The first group identified the fundamental laws along with their mottos and weaknesses. The second group found the line ministries and divisions having stakes directly and indirectly in marine and environmental management. They also scrutinized the respective mandates from the "Rules of Business 1996" and overlapping jurisdictional areas. Two divisional workshops were held in Khulna and Barishal, where approximately 50-60 participants were present in each. The divisional workshops' purposes were to identify the causal factors of non-compliance with laws and conflict of interests. All of the groups were requested to come up with the solutions for overcoming the challenges.

Three Focus Group Discussions (FGDs) were done at Bangladesh Oceanographic Research Institute, Marine Fisheries Academy, and Bangladesh Marine Academy, taking 5-8 respondents in each to understand the coordination mechanism among training and research institutes. In addition, seven case studies were done at Andharmanik, Nilkamal, Jamtola Beach, Mongla Port, Lalkakrar Char, Laboni beach, and Cox's Bazar-Teknaf Marine Drive to generate an idea about the coordination mechanism and management practices at the operational level (Figure 1a). A total number of 120 individuals were interviewed by using a semi-structured questionnaire at Jhaliaghata (Patharghata sub-district), Boromasua (Mathbaria sub-district), and Mohipur (Kalapara sub-district) to identify the critical challenges of the artisanal and small-scale fishers. A total number of 20 key informants, including academicians and line experts, were interviewed to identify the potential resources.

\subsubsection{Australia}

A 'Coastal Mini-Symposium, 2019' was held at the Macquarie University of Australia, where researchers from different institutes of Australia presented papers on institutional and legal aspects. A total number of ten research works were presented in that symposium. A professor from the University of Bologna, Italy, delivered a keynote paper on the sustainable marine-urban ecosystem. Similarly, seven case studies were done from "Northern City Council," Sydney; "The Green Island" ("The Great Barrier Reef," Queensland; the "Great Ocean Road," Victoria; the "Bruny Island," Tasmania; Scarborough beach resort, Perth; Surfers Paradise, Gold Coast; and the Davenport, Tasmania (Figure 1b). These case studies were carried out to understand the local government and community's role in managing marine resources together with the operational and coordination mechanism. 


\subsection{Data analysis}

The content analysis was done considering its uniqueness, which supports qualitative (Dooley, 2016) and quantitative research (Krippendorf, 2004; Neuendorf, 2002; Spencer et al., 2003) in an inductive and deductive way. The collected data was coded into different categories and variables. The study preferred a manifest content analysis rather than a latent content analysis to reflect the respondents' total views avoiding biases (Berg, 2009). Four stages: de-contextualization, re-contextualization, categorization, and compilation were followed in the content analysis (Bengtsson, 2016).

\section{Results And Discussions}

\section{Potential Marine Resources in Bangladesh}

According to key informants' perception, Bangladesh has a broader scope in bolstering the blue economy within its Exclusive Economic Zone (EEZ) and the high sea. The potential resources of the Bay of Bengal and coastal areas include both living and non-living resources. Sustainable use of fisheries, mariculture, aquaculture, biotechnology, maritime shipping, seaports, maritime shipping, minerals, energy sources, tourism, trade, and commerce can create enormous opportunities for Bangladesh generating decent works for the citizens and upscaling the livelihood of the community.

\section{Living resources}

The deeper areas within the Exclusive Economic Zone (EEZ), notably the southern patches, middle zone, and the Swatch of No-ground of Bangladesh and the high sea, are rich in tuna and large pelagic fishes. The marine fisheries, mostly finfish harvesting, constitutes only $20-24 \%$ of the total fish production in Bangladesh; in contrast, large scale mechanized fishery contributes only $14.2 \%$ of the full marine extractions (DoF, 2017). A total of 475 species of marine fishes were discovered in the EEZ so far, comparing 250 species in the freshwater. The marine fisheries harvesting is confined to the shallow water (50 meters depth) in the estuary and territorial water (up to $60 \mathrm{~km}$ from the shore) (Hussain et al., 2017). Among the pelagic fishes, only Hilsa, Pomfret, Bombay duck, and Ribbon Fish are caught from the upper zone of water near the shore's proximity. Other pelagic species like Indian Salmon, Mullets, Oil Sardine, Butter Fish, Sword Fish, Bonito, Pike, Skipjack, Smelts, Threadfin, Anchovy, Dorab Herring, and Indian Scad are in out of the catch mostly. Likewise, the demersal fishes Croakers, Flatfishes, Catfishes, Sea Breams, Pike, Snappers, Eel, Scavengers, Crabeater, Goat Fish, Rock Fish, Rabbit Fish, Seabass, Grouper, Silver Bream, and Ribbon Fish are nearly untouched due to the absence of equipped fisheries vessels and long lines catching within EEZ. Furthermore, high sea fishing is almost absent in Bangladesh. Sustainable extraction of marine fishes can boom the economy, creating a multi-dimensional scope.

Despite the potentials and opportunities for developing mariculture in the coast, nearshore, and offshore areas, Bangladesh could not develop commercial farming of finfish, shellfish, and seaweeds. The Chittagong division is considered a friendly habitat for pearl culture though it has not been initiated to date. Over the decades, the country flourished brackish shrimp culture in mangrove areas, fueling the 
salinization and jeopardizing the fresh swamp's ecosystem. The non-traditional species include seagrass, macroalgae, oyster, mussel, sea cucumber, sea urchin, etc. (Ahmed and Rahman, 2020; Hussain et al., 2017). It is widely possible to culture marine fishes like Sea Bass, Black Asiatic Sea Bass, Mullets, Pomfret, and different crustaceans in the inshore and offshore areas. To combat climate change, "Integrated Multi Trophic Aquaculture (IMTA)" can be an innovative process of growing different finfish and shellfish in association with the seaweeds (Ahmed and Glaser, 2016).

The Sundarbans mangrove is an ideal habitat for few honeybee species like Apis dorsata, Apis cerana, and Apis mellifera, as many plant species provide pollens and water all time. The mangrove has a natural resilience against forest fires, and it naturally deters termites and ants. The reproduction of 'Black Mangrove' or 'Honey Mangrove' (Avicennia germinans) depends on bee pollination. World-famous lotus honey is produced from the tree species, Khalsi (Aegiceras cornicuiatum). The crude honey collected by the traditional way is a mixture of raw wax, plant debris, pollens, and larvae of a bee; resultantly, it follows a fermentation process within a short time. Hence, scientific apiculture may help in developing agroindustry.

The scope of adopting marine biotechnology in Bangladesh is promising as the mangrove and marine water is highly rich in microalgae, a raw material of many life-saving pharmaceutical drugs. However, nearly 200 marine algal taxa (seaweeds) have been found so far. Proper collection of strains followed by preservation and utilization may generate alternative energy sources like bio-fuel. Microalgae grow well in coastal areas of Bangladesh, notably the Sundarbans mangrove. Like other vegetables, the edible seaweeds can meet the need for protein, carbohydrate, and lipids. Many species produce triacylglycerol, high-value fatty acids, vitamins, and other food supplements. Spirulina powder is being used in the country for a long time.

The Nypa palm is highly abundant in the mangrove areas whose inflorescence can be tapped to capture the sweet sap for producing jaggery, sweet syrup, and finally, sugar. The juice can be fermented to make an alcoholic beverage, vinegar, and acetic acid. The flower petals can be used as an aromatic tea due to the presence of sweet scents.

\section{Non-living resources}

The Bengal delta is rich in hydrocarbon-bearing sediment; on that ground, the respondents assumed that there might be significant quantities of exploitable natural gas reserves in the Bay of Bengal based on its geological and geophysical characteristics. More drilling program is urgent to find exploitable natural gas reserve in the Bay. Meanwhile, Myanmar has discovered some blocks at the proximity of Bangladesh's border. Therefore, Bangladesh is likely to have deposits of natural gas and crude oil. For the same reason, it is believed that valuable heavy minerals are to be found in the beach sand across a $250 \mathrm{~km}$ coastal belt from Patenga to Teknaf. The deposit of 17 valuable minerals (zircon, magnetite, rutile, leucoxene, ilmenite, garnet, kyanite, monazite, etc.) was found in the entire coastal belt (Alam, 2014). Proper initiatives are to be taken to extract and commercialize the minerals from beach sand, which will enhance the growth of different industries. 
Bangladesh can utilize the vast shipping and associated opportunities in the Indian Subcontinent region and even in China due to its geographical position and $710 \mathrm{~km}$ long coastline. About $90 \%$ of the country's overseas trade is seaborne; in contrast, the national flag bearing vessels meet less than $5 \%$ need. Every year Bangladesh pays more than 10 billion USD to overseas ship companies to meet its requirement (Alam, 2014). Self-dependency in this sector may be a coin changer for Bangladesh. Similarly, Bangladesh can easily connect India, Thailand, Sri Lanka, Singapore, Malaysia, and Myanmar through introducing maritime feeder services. The Seaports of Bangladesh can be are used for various economic activities like international shipping, passenger ferries, cruise shipping, coastal shipping, fishing, mining, oil drilling, and maritime monitoring. The enhancement of the existing capacities of seaports can facilitate the country's increased trade and commerce. The seaports can be used by land-locked Nepal, Bhutan, and seven sisters of India. Even China may have interests in the establishment of modern seaports.

Bangladesh shipyards stress on manufacturing inland water vessels instead of marine vessels due to its capacity limitations. The up-gradation of the manufacturing and engineering fronts, including repairing facilities, may boost up this industry. Considering the cheap labor resources, Bangladesh also can walk for developing this sector. On the same ground, Bangladesh can expand the ship recycling industries for meeting the needs of scrap steel, which is a raw material for steel and re-rolling mills and can save huge foreign currency. The salt industry in Bangladesh has a long history, which started in the early of Portuguese colonialism. The country has attained self-sufficiency in producing salt though it follows very traditional technology. By adopting modern technology, the country can multiply its production to export. Community-based land management systems, sufficient credit facilities, mechanization, and access to early weather forecasting can boost production by exploiting the same resources.

Wind, wave, tide, and currents of the Bay of Bengal offer a significant potential to contribute blue energy. Floating wind turbines in the offshore may generate power for Bangladesh. Blue tourism can create decent works, promote local culture and products, and reduce poverty. Bangladesh has a vast scope of expanding marine-based tourism in Cox's Bazar, Patuakhali, Bagerhat, Khulna, and Satkhira district. The marine drive (80 KM long) located in Cox's Bazar district may attract the foreigners for yachting, water sports, and marinas if a separate zone is created with full of fun making facilities considering the socioreligious values. To minimize the mainland's demographic pressure, Bangladesh can construct infrastructure in its existing 75 marine islands, followed by littoral plantation. Those Islands can be used for tourism and port as well.

\section{The legal framework}

\section{Bangladesh}

The respondents identified a total number of 21 laws that support marine resource management and sustainability directly or indirectly (Table 1). Article $18 \mathrm{~A}$ of the Constitution, without keeping any specific 
provisions, upholds the aspiration of sustainability of natural resources. This section was included in the "Fundamental Principles of the State Policy," which is judicially non-enforceable. "Territorial Waters and Maritime Zones Act, 1974" zoned the Bay of Bengal, discounting the concept of marine governance and not accrediting any specific ministry or department as the custodian of this law, though MOFA serves the purpose. The drafted "Bangladesh Maritime Zones Act, 2018" is an amendment of the act mentioned above, approved by the cabinet but not ratified as a bill through the parliamentary process. This draft also underlines the determination of the maritime zones and control of criminal activities. Therefore, the concept of marine governance has been flourished in Bangladesh.

\section{Table 1: List of key laws identified by the respondents}

SL Name of the law

1 The Constitution of the People's Republic of Bangladesh

2 The Territorial Waters and Maritime Zones Act, 1974

3 Bangladesh Maritime Zones Act, 2018 (Draft)

4 The Marine Fisheries Ordinance, 1983

5 The Protection and Conservation of Fish Rules, 1985

6 The Bangladesh Shipping Corporation Act, 2017

7 The Bangladesh Merchant Shipping Ordinance, 1983

8 The Bangladesh Flag Vessels (Protection) Ordinance, 1982

9 The Bangladesh Ship Recycling Act, 2018

10 The Bangladesh Oceanographic Research Institute Act, 2015

11 The Bangladesh Oil, Gas and Mineral Corporation Ordinance, 1985

12 The Sustainable and Renewable Energy Development Authority Act, 2012

13 Weather Act 2018

14 The protected areas of tourism and special tourism zone Act 2010

15 Bangladesh Water Act 2013

16 State Acquisition and Tenancy Act 1950

17 Bangladesh Environment Conservation Act 1995

18 Wildlife (Conservation and Security) Act 2012

19 Ecologically Critical Area Management Rules 2016

"Bangladesh Merchant Shipping Ordinance, 1983" and "Bangladesh Flag Vessels (Protection) Ordinance 1982" and "Bangladesh Ship Recycling Act, 2018" entrusted MOS to administer maritime shipping and shipyard industry. However, shipping related laws are not accommodative with international conventions.

Marine Fisheries Ordinance, 1983" empowered MOFL to manage marine including high sea fisheries, in contrast, "Wildlife (Conservation and Security) Act, 2012" empowered the Ministry of Environment, Forest and Climate change (MOEF) to regulate the protected areas, including their resources. Interestingly, the 
"Bangladesh Merchant Shipping Ordinance, 1983" entitled MOS for the registration of fishing vessels. Hence, Marine Fisheries are intersected by 03 ministries, which cause a conflict of interests and an obstacle in marine fisheries development in Bangladesh. "The Protection and Conservation of Fish Rules, 1985 " underlines freshwater fisheries by downplaying the marine realm.

Similarly, MOEF also controls Marine tourism in the protected areas being empowered by the "Wildlife (Conservation and Security) Act, 2012". Contradictorily, the "State Acquisition and Tenancy Act 1950" authorized the Deputy Commissioner $(D C)$ of a district on behalf of the Ministry of Land (Minland) to maintain the rights in and over land and water. Hence, tourism in the non-protected areas is managed by the district administration. "The protected areas of tourism and special tourism zone Act, 2010" authorized the Ministry of Civil Aviation and Tourism (MOCAT), the nodal institute to regulate tourism. Likewise, this sector faces onslaught overlapping and underlapping jurisdictions and cannot move forward. Differently, "Ecologically Critical Area Management Rules, 2016" provided some authority to $M O E F$ in land management, which has created a conflict of interest with Minland.

The "Bangladesh Oil, Gas and Mineral Corporation Ordinance, 1985" entrusted MPEM to explore, extract and sell crude oil, natural gas, and mineral resources. The "Sustainable and Renewable Energy Development Authority Act, 2012" entitled this ministry to explore non-traditional renewable energy sources.

The study revealed that only the "Territorial Waters and Maritime Zones Act, 1974"; "Marine Fisheries Ordinance, 1983"; "Bangladesh Flag Vessels (Protection) Ordinance, 1982"; and "Bangladesh Oceanographic Research Institute Act, 2015" deals with few areas of the blue economy. Ironically, the provisions of the "United Nations Convention on the law of the sea (UNCLOS)" and the "International Convention for the Prevention of Pollution from Ships (MARPOL)" are overlooked in the existing laws. The "Bangladesh Biodiversity Act, 2017" and "Wildlife (Conservation and Security) Act, 2012" somehow cover the obligations of the "Convention on Biological Diversity (CBD)" and "Aichi Biodiversity Targets". But these laws were enacted for eyeing on terrestrial ecosystems. Bangladesh is a signatory country of approximately 45 international treaties for ensuring sustainability, nature conservation, and environmental justice (Rahman 2021g). "Bangladesh Environment Court Act 2010" does not directly recognize ordinary people's rights, and the Court's jurisdiction is unclear.

\section{Australia}


The "Fisheries Management Act, 1991" provided a clear guideline of marine fisheries management outlining the Federal Government, the constituent States, and the Northern Territory's jurisdiction. This act framed an independent statutory authority known as the "Australian Fisheries Management Authority (AFMA)" for managing fisheries on behalf of the Federal Government. This act covered all aspects of marine fisheries, including management and conservation.

The "Navigation Act, 2012" was enacted to ensure maritime safety and prevent marine pollution incorporating the latest international standards for seafarer living and working conditions under the "Maritime Labour Convention, 2006". This act authorized the "Australian Maritime Safety Authority (AMSA)" to act as the National Regulator.

The "Offshore Petroleum and Greenhouse Gas Storage Act, 2006" covered the regulatory framework for exploring offshore petroleum in Commonwealth waters. Besides, the "Offshore Minerals Act, 1994" spelled out the provisions of exploring and extracting minerals (other than petroleum) within the first three nautical miles of the territorial water. The "Renewable Energy (Electricity) Act, 2000" was enacted for exploring renewable energy sources, including wave, tide, and ocean.

The "Environment Protection and Biodiversity Conservation Act, 1999" enabled the federal government to join with the states and territories in providing a truly national scheme of environment and heritage protection and biodiversity conservation. The "Great Barrier Reef Marine Park Act, 1975" commenced establishing a "Great Barrier Reef Marine Park" providing a guideline for the long-term conservation and protection of the biodiversity, environment, and biodiversity and heritage values of the reef.

From the above discussions, it is evident that Australia's legal framework has enacted sectoral laws providing a clear mandate for the public institutions and avoided jurisdictional overlapping and conflict of interests. Simultaneously, the legal framework covers all corners of marine resource management, sustainability, and present and future challenges incorporating international obligations. Despite having an advanced legislative framework, Australia, a federation, encounters problems establishing jurisdictions on the landscape across the states and territories, contemplated as a historical legacy problem. Inconsistencies in jurisdictions for the federation, states, territories, and local stem a complex legal landscape, which pounds a regulatory burden for intra-state actors and weakens the authorities' cohesion, hindering the implementations (Yin and Techera, 2020). 


\section{Bangladesh}

The respondents identified numerous actors having stakes in marine resource management (Table 2). The relevant businesses were scrutinized from the "Rules of Business, 1996' (Cabinet, 2017). The mandates of recently formed MAU have not been included in the business allocation of MOFA. MOS plays a crucial role in administering maritime transportation where its apical business is 'port,' a single word without further clarification that can denote various ports, including spaceport. The clear mandates of MOFL could not clear deadlock over fisheries management as its counterpart MOEF is entrusted with a highly ambiguous mandate. Environment and ecology can be applied to a broader range from benthic to avian ecology. Climate change is absent in the business of MOEF despite its presence in the nomenclature of this ministry.

Table 2: Allocations of business for the ministries/division related to marine resource management in Bangladesh (Cabinet, 2017) 


\begin{tabular}{|c|c|}
\hline$M / D$ & Allocation of business \\
\hline MOFA & $\begin{array}{l}\text { Boundary and territorial treaties; piracies and crimes committed on the high } \\
\text { seas, and administrative zonation }\end{array}$ \\
\hline MOFL & $\begin{array}{l}\text { Aquaculture including pearl culture, marine fisheries, deep-sea fisheries, and } \\
\text { shrimp culture in the coastal areas }\end{array}$ \\
\hline MOS & $\begin{array}{l}\text { Ports, maritime shipping, navigation, controlling offense on high seas; marine } \\
\text { pollution from ships and crafts; registration and safety administration of } \\
\text { fishing vessels; marine search and rescue }\end{array}$ \\
\hline$\overline{M P E M}$ & Energy, petroleum, natural gas, mineral resources, and geological survey \\
\hline MOEF & $\begin{array}{l}\text { Environment and ecology; environmental pollution; conservation of forests; } \\
\text { protection of wild birds and animals; and establishment of sanctuaries }\end{array}$ \\
\hline MOCAT & Legislation relating to tourism and registration of travel agencies \\
\hline$\overline{I S D}$ & Internal and border security \\
\hline$M O D$ & $\begin{array}{l}\text { Meteorological observations, hydrographic surveys, and preparation of } \\
\text { navigational charts }\end{array}$ \\
\hline MOST & Biotechnology and oceanographic science \\
\hline Mincom & $\begin{array}{l}\text { Matters related to export including treaties, agreements, protocols, and } \\
\text { conventions bearing on trade with other countries }\end{array}$ \\
\hline$M O D M R$ & $\begin{array}{l}\text { Issues related to risk reduction, emergency response management, relief } \\
\text { management, rehabilitation, safety net programs }\end{array}$ \\
\hline$L G D$ & $\begin{array}{l}\text { Development of rural water supply, sanitation and sewerage system; taking } \\
\text { poverty reduction program; and promoting entrepreneurship development }\end{array}$ \\
\hline$\overline{M O A}$ & Regulating agricultural inputs \\
\hline Minland & Issues related to rights in and over land and water \\
\hline Moind & Matters related to the industry, salt industry \\
\hline GED & $\begin{array}{l}\text { Geographical Information System (GIS) platform; the national focal point of } \\
\text { renewable sources of energy }\end{array}$ \\
\hline MSW & $\begin{array}{l}\text { Community development with particular emphasis on the disadvantaged } \\
\text { segment of the society }\end{array}$ \\
\hline MOWR & $\begin{array}{l}\text { Land reclamation and estuary control; controlling salinity and desertification; } \\
\text { hydrological survey }\end{array}$ \\
\hline Moedu & Matters related to public universities \\
\hline
\end{tabular}

$M / D=$ Ministry/ Division; $M O D M R=$ Ministry of Disaster Management and Relief; MOWR=Ministry of Water Resources; $I S D=$ Internal Security Division; Moind= Ministry of Industries; Mincom=Ministry of Commerce; $M O A=$ Ministry of Agriculture; $L G D=$ Local Government Division; $M S W=$ Ministry of Social Welfare 
Instead, MODMR is entrusted with a transparent mandate like risk reduction, emergency response. The business allocation did not strengthen the footings of MOCAT in overseeing blue tourism as it is mandated to deal with tourism centric legislatures. The Mind has been empowered to regulate the salt industry, a piece of the marine industry though it was supposed to be the nodal ministry of developing maritime industry. Being a focal point of renewable energy sources, GED has coincided its mandate with the parental MOPMR dealing with energy.

MOST deals with the matters associated with biotechnology and oceanographic science, but simultaneously, Moedu is mandated for technical education and research. On the other side of the coin, the "Bangladesh Oceanographic Research Institute Act 2015" enabled the "Bangladesh Oceanographic Research Institute" to control and coordinate all marine research. Bangabandhu Sheikh Mujibur Rahman Maritime University (BSMRMU), the only earmarked university, is administered by the AFD. Several public universities have marine-related faculties, departments, and disciplines which follow the guideline of Moedu. Bangladesh Marine Fisheries Academy, a MOFL-run training institute, was established to prepare graduates for marine fisheries that currently offer a bachelor's degree in nautical and marine engineering with higher interests. As MOFL is not entitled to issue a Continuous Discharge Certificate, the nautical science and marine engineering departments' cadets must collect MOS certificates. With this, the unique role of Bangladesh Marine Academy, a sub-ordinate MOS organization in preparing mariners (nautical and engineering), has been fizzled out. Both these training institutes are affiliated with BSMRMU through sidestepping Moedu and MOST.

$L G D, M S W$, and MODMR work for the development of the coastal community without maintaining demarcated boundaries. Interestingly, the role of local government bodies in managing natural resources has been endorsed in its mandate. Hence, the concept of local governance in marine and coastal resource management is under dark.

It is revealed that the fragmented legal framework and ambiguities in business allocation resulted in jurisdictional overlapping in almost all areas of resource management (Figure 2). Therefore, the institutional framework for coastal and marine resource management is characterized by a complex arrangement. The study found many public institutes in Bangladesh regulate the blue economy and environmental protection, but their mandates are not clearly defined either in the legal or institutional framework.

The jurisdictional overlapping leads to a conflict of interest, poor coordination, lack of cohesion, and even rivalry, which are the major pitfalls and bottlenecks in harnessing marine resources in Bangladesh (Figure 3). Very often, everybody's business turns into nobody's business.

It was argued that poor coordination and integration mechanisms exist among various stakeholders, neither from the policy level to the implementation level. There are few institutions established by the legal provisions for regulating the marine and coastal resources. The vagueness in the allocation of business in determining the authority created obstacles in developing effective coordination, hindering further blue growth. The absence of formal institutional mechanisms and poor coordination among 
public departments also caused the degradation of marine living resources (Rahman $2021 \mathrm{a}, \mathrm{e}$ ). The fisheries resources are managed by disconnected agencies, causing competition and conflict of interests among different departments (Hossain et al., 2014). The sectoral, temporal, and spatial marine governance is neither supported by the legal nor institutional framework resulting in poorly functional marine governance. Hussain et al. (2017) reported that lack of coordination between and among the players negatively impacted marine trade and commerce, blue tourism, exploration of minerals, marine industries, sustainable marine fisheries, conservation, and social welfare. The coastal and maritime tourism in Bangladesh faces enormous challenges due to poor coordination and integration among different sectors (Rahman and Hossain, 2020a). The multi-layered authorities generate miserable sufferings for the artisanal fishers (Rahman 2021a, h). Sarker et al. (2018) revealed that along with government functionaries, academic institutions, NGOs, and think tank organizations should be the critical stakeholders in the marine regulation.

\section{Australia}

The study reveals that Australia engaged few public departments to oversee all elements of the blue economy (Figure 4). "Department of Agriculture, Water, and Environment," the SDGs' focal point of Australia, is responsible for managing all living resources, including conservation, tackling climate change, and implementing the green army program. Several statutory bodies like boards, advisory groups, and committees, help the government develop and upgrade marine policy and cement the coordination mechanism. Among them, the "National Ocean Ministerial Board (NOMB)"; "Ocean Board of Management (OBOM)"; "National Ocean Advisory Group (NOAG)" and "Ocean Policy Science Advisory Group (OPSAG)" play a critical role in shaping the marine policy. Concurrently, the public departments formed several authorities to work on different dimensions independently. "The Australian Volunteer Coast Guard" is mandated for maritime search and rescue; offshore vessel tracking; recreational vessel monitoring; marine radio monitoring; marine license; marine radio license; and coast navigation.

"Geoscience Australia" provides information regarding coasts and estuaries; seabed mapping; Antarctica; natural risk; hazard and disaster; coastal erosion; minerals exploration; mining; and land use.

The allocation of business for different government institutions is clearly defined without creating chaotic conditions like Bangladesh. The departments of State and Territory Government follow the business of the Federal Government. Still, Australia also faces challenges rooted in multi-jurisdictional fisheries management and continues amending the regulation. Australia continues to build a strong partnership among ecologists, managers, and recreational fishers (Boon and Baxter, 2020).

\section{Governance at the implementation level}




\section{Bangladesh}

Andharmanik. Andharmanik (the ruby of the dark), a hidden treasure trove in the Sundarbans mangrove, is characterized by a fresh-brackish swamp and intercepted by four rivers: the Shela, Kharma, Baleshwar, and Chechang. This area is earmarked as a dolphin sanctuary that is lack of tourist amenities. The Chandpai range of Forest Department manages this tourist spot's diverse plant ecosystem and herds of wild spotted deer.

Nilkamal: Despite the absence of tourist facilities, abundant spotted deer, Bengal Tiger, Marsh Crocodile, Rhesus Monkey, Peacock Turtle, Red Junglefowl, and rare birds has heightened the natural beauty of Nilkamal (blue lotus), a highly famous tourist spot in Bangladesh. Similarly, it is regulated by the Khulna range of the Forest Department.

Jamtola Beach: Jamtola (under the blackberry tree) is located in the East Wildlife Sanctuary of the Sundarbans mangrove, an exciting tourist spot. The array of littoral vegetation has enriched this beach, an exact location for watching the realistic view of sunrise and sunset over the sea. A nearby watchtower is considered the only tourist facility for this beach controlled by the Shoronkhola range of Forest Department.

Mongla Port: The port is managed by a port authority comprised of the Chairman (Chief Executive) and three members under MOSs control. The Standing Committee on Ministry of Shipping lead by Members of Parliament monitors the authority's activities simultaneously. The board is entitled to formulate a policy of the administration, operation, and development.

Lalkakrar Char: Lalkakrar Char (shoal of red crab) is about five km east from Kuakata's main beach point under Patuakhali districts, an attractive place for the thousands of nature lovers. These little mermaids (red crabs) come out of the residing holes during low tide turning the beach into a red carpet. The Tamarix stands beside the beach makes a red-green nexus at that time. The conflict of interest is absent in this underdeveloped beach apart from tourism amenities.

Laboni beach: This is the part of the world's longest natural sandy beach (125 kilometers), the most popular tourist spot of Bangladesh, which remains crowded by thousands of visitors over the year. The restaurants, resorts, cottage, and lobster's market are managed by the private sector fragmentally. With the help of Bangladesh Tourist Police, the district administration, Cox's Bazar ensures safety for the tourists. There is a lack of specific authority empowered by the law responsible for spatial planning, day to day maintenance, development of tourist facilities, and sustainability.

Cox's Bazar-Teknaf Marine Drive: The longest marine drive road in the world is surrounded by a hilly evergreen forest on one side and blue marine water on another side. On $80 \mathrm{KM}$ long road, few substandard restaurants are available in Inani and Himchhori beach points; hence it could not be ideal spot for tourists, notably foreigners. Bangladesh Army, Bangladesh Police, and Bangladesh Border 
Guards have checking points at the intervals, and hence, it is quite tricky to find the actual authority of this drive.

The study reveals that the local government bodies play a perplexing role in marine and coastal resource management. On the other hand, the active participation of the community has not been embraced yet. Not only the community-based ecotourism but also sustainable tourism is impoverished. Both the existing legislative measures and institutional mandates do not endorse the community's role in the decision-making and implementation processes. Due to centralized and bureaucratic type of management systems (Giessen et al., 2016), the Public Departments could not ensure the full participation of the community and other stakeholders in the natural resource management (Millat-eMustafa, 2002; Rahman 2021a, Rahman and Akter 2020).

\section{Australia}

The northern beach council: Local governments in South Australia were empowered under the "Local Government Act, 1999" and the" Development Act, 1993" to manage the coast. The local governments play a crucial role in beach management. The population of the Northern City Council is 266,000 . The council is responsible for an active and healthy lifestyle with clean waterways, beautiful wildlife, and vibrant events backed by outstanding services and infrastructure. Managing Coastal ecosystems is a significant priority; hence the council guides and regulates land development processes to provide local services and manage public land. Strong community involvement is critical to its success. It prepared "Community Strategic Plan, 2028" with the consultation of the communities. The council manages coastal erosion, headlands, rock platforms, coastal lagoons, creeks, middle harbor, Pittwater waterway, wetlands, water resources, and cleans up ocean pollution. It is committed to protecting trees and bushland on the Northern Beaches as well. On the other hand, it has adopted a community-based adaptation of climate change; resultantly, the "Manly Environment Centre (MEC)" works under this council, promotes sustainable living practices through practical projects. Besides, the MEC is an advocacy, research, education, and resource center which does everything to keep the environment and residents safe from the impact of hazard and disaster.

Surfers Paradise, Gold Coast: The City Council of Gold Coast manages, maintains, and protects the Surfers Paradise beaches all year-round. It is responsible for managing beaches, maintaining and constructing seawalls, sand pumping, dredging, and landscaping. The council works to develop coastal infrastructure, protect the coastline against erosion from future storms, renew the artificial reef to protect its narrow stretch of the foreshore, restore dune amenity, and increase the dune system's health. The council promotes stage events and entertainments in collaboration with event partners accompanied by 
managing and operating the beachfront markets. Accordingly, it conducts market research, liaises, and works with the local traders and businesses concerning their objectives. The council also looks after community partnerships, community education, planning for environment, landscape protection, conservation of wildlife, water resource management, waste management, and recycling.

The Green Island (The Great Barrier Reef): The reef area adjacent to this island was declared as the "green zone" or "no-take zone," where fishing or extraction of resources is strictly prohibited. The nearby reef, beaches, and public areas of this Island are a "recreational area," including a jetty, a public esplanade, mooring areas, navigation channel, and the marine park out to $1.6 \mathrm{~km}$ from the edge of the reef. The park is managed by the "Queensland Parks Service empowered by the distinct regulatory and institutional framework. There is a guideline for limiting the number of visitors per day, prohibiting certain activities like fishing or mechanized water-sports, and snorkel trailing. Facilities management, fees, damage bond, fines, rewards, publication, cultural activities, research, and education are spelled out in the guideline. A recreation levy provides funds for expanding visitor's facilities and environmental conservation.

The Great Ocean Road: The Great Ocean Road, a National Heritage Site of Australia, is regulated by the "Great Ocean Road Coast Committee" that is legitimated by the "Crown Land (Reserves) Act, 1978". The committee members are selected from a wide range of stakeholders. They are appointed by the Minister of" Environment and Climate Change." Building partnership with the community, the committee manages these iconic coastal reserves of Victoria. The committee builds and maintains a wide range of public amenities, assets, and infrastructure. They also tend to lease one privately operated park by issuing licenses and permits for various commercial and one-off activities. The committee is also responsible for enhancing and effectively managing the coastal environment by reinvesting the income generated through caravan parks, leases, permits, and licenses. By prioritizing the cultural heritage with the utmost importance and improving the educational access, it fosters partnerships and volunteerism built on mutual trust, open communication, collaboration, and glassiness. The evidence-based decision is made based on the available data and information to inform the community about the planning beforehand.

Davenport: The management of "Davenport" started in 1992 as Budget Property Management; furthermore, it was converted into "Davenport Professional Property Management" in 2004 that focuses on smart and one-stop customer service. The management consults with many stakeholders from Board Members, homeowners, Attorneys, Real Estate Agents, and all kinds of Association Vendors. The number of associations was increased from 8 to 70 during 2004-2019. The management promptly responds to any calls. Everyone at Davenport is motivated to communicate very quickly through. The digital proficiency helps them be a quick problem solver. 
The Bruny Island: The "Kingborough Council" is responsible for managing this South Tasmanian Island and committed to caring for the natural environment, including bushland and coastal areas. It is also mandated to develop and protect a network of healthy natural and coping ecosystem. "The Natural Resource Management Unit" is involved with various roles like vegetation management, weed control, supporting environmental volunteers, and improving urban stormwater discharges. Besides, the "Bruny Island Advisory Committee (BIAC)" is formed by the council for maintaining a communication link between the community and the Council.

Scarborough beach resort: This coastal suburb was named from the British North Yorkshire's beach resort, Scarborough. The "City Council of Stirling" is responsible for managing this beach and protecting the natural environment, including wildlife, so that future generations can continue to enjoy a sustainable lifestyle. It also facilitates and oversees the staging of various activities, promotions, events, competitions, and much more held along the coastline ensuring, the community's safety and compliance of local laws and legislation.

The social responsibility of salient stakeholders in organizational operations processes in contemporary dynamic environments is not well-shaped yet. The assertion of Indigenous peoples' rights and the ongoing fight to combat colonization's legacy affects Australia's participatory marine governance (Bray et al., 2019). Australia needs more initiatives for adopting more sustainable governance to enhance a social license for managing both regulators and regulates (Bolton et al., 2020). Therefore, Australia can adopt responsive regulation and associated stakeholder engagement to achieve more sustainable management.

\section{Fishers' Challenges in Bangladesh}

The fishers identified piracy as the greatest threat indicating futile legal and institutional arrangement, non-compliance with the laws, laxity in enforcement, and ineffective MCS. Due to a lack of high sea governance, foreign pirates frequently enjoy hegemony in the sea. The fish stock is declining in the estuary and territorial water for the commercial fishers' ascendancy and destructive fishing, albeit prohibited per "National Fisheries Policy 1998". Shamsuzzaman and Islam (2018) revealed that this policy is not implemented due to DOF laxity. Sometimes, the fishers suffer tremendous hassles, including red-tapism and bribery, at fishing vessel registration. The formal banking system does not offer loans to the fishers though it is the constitutional right to be treated equally as the country's permanent residence. It can be argued that DOF could not establish a coordination mechanism with the Financial Institutions; thus, the fishers depend on Mahajan (local moneylenders). They pay back a 100\% interest rate, which propels vulnerability and poverty. This local credit system is notoriously known as Dadan. 
The fishers found seven groups of intermediaries in the fish market chain: collector, majhi (the Captain of the boat), Chhoto Mahajan (small moneylender), Boro Mahajan (big moneylender), Aratdars (a commission agent for stocking), wholesaler, and retailer (Figure 7). Jointly Chhoto Mahajan and Boro Mahajan make the highest profit, which is equal to more than $50 \%$ of the retail price, while the other groups make $25-30 \%$. As the fishers cannot sell the harvested fish to the consumers directly, they are bound to be happy with $20-25 \%$ of retail prices. In Bangladesh, the agricultural market and supply chain are distorted and fragile, controlled by intermediaries (Alam et al. 2021, Rahman 2021 a, b, c, d). Before going to the sea, fishers collect weather forecast as there is no mobile phone network coverage there, while a segment depends on only radio.

\section{Recommendations}

\subsection{Legal reforms}

Taking lessons from Australia, Bangladesh can enact sectoral to abolish jurisdictional overlapping and conflict of interests. Beforehand, a law commission can be formed to identify the conflicting issues in the segmented laws. The new laws should incorporate international commitments and obligations, and the problems of sustainability and conservation.

\subsection{Reallocation of business}

After necessary legal reforms, the business for a few ministries and divisions should be reallocated to downsize the number of actors for making sure that anyone's business is not everyone's business considering Australia's experiences.

By considering the chaotic conditions in living resource management, marine industries, blue energy, maritime security, coastal management, and local governance, mandates' reallocation has become inevitable. Hence, the study recommends the amendments of the "Rules of Business, 1996".

"The Maritime Affairs Unit (MAC)" working under the "Ministry of Foreign Affairs" can be graduated to a separate and independent ministry to establish effective coordination with other ministries. Like Australia, national and sectoral statutory bodies, councils, and boards can be formed to formulate national marine policy. In addition, they will help different ministries in taking appropriate development projects and management schemes. A National Marine Education and Research Committee could is highly warranted to integrate research works and coordinate among researchers. MOFA should be entitled to be the focal point of high sea governance following UNCLOS so that it can coordinate with other marine states shared by the Bay of Bengal. The roles of the Bangladesh Navy and Coast Guard should be clearly defined to 
accelerate the Monitoring, control, and surveillance (MCS). $L G D$ should be empowered to oversee the local governance for natural resource management.

\subsection{Policy interventions}

Bangladesh needs a comprehensive separate marine policy highlighting sectoral priority areas, coordination mechanism, and community welfare. Without the community's active participation and wholehearted support, it will be challenging to ensure any programs' sustainability. Either comanagement or ecosystem-based management can ensure participatory governance, conservation, and finally, sustainability. The commercial fishers should be motivated to harvest pelagic fishes and introduce high sea fishing to establish artisanal and small-scale fisher's right and protect further decline of fish stock in the estuary and territorial water. The Bangladesh coast guard's proactive role can control piracy and robbery in the sea and coastal areas. The marketing system can be modernized by clearing the intermediary's group from the market chain. DOF should coordinate with the formal banking system to disburse loans for the community people, which are warranted to stop the local lenders' (Mahajan) monopoly business and improve the socio-economic conditions. The departments, notably $D O F$, should be equipped with modern logistics and a sufficient workforce. The community-based tourism helps in employment generation and branding of local products and culture. Fish telemetry technology or community radio for fishers could be installed in the coastal area to forecast weather and provide fishing guidelines.

A buckled cohesion of the public departments, researchers, academia, non-government organizations, private sectors, training institutes, research institutes, and the community can maximize the benefit without ecological degradation. The coordination among marine states is essential for conservation and tackling climate change. One country's conservation initiative may be jeopardized by the over-extraction and destructive activities of other countries. For optimizing the benefits, the marine stakeholders need to consider the undeniable role of the land managers.

Considering the environmental degradation caused by increased salinity (Rahman 2020, Rahman et al. 2021), Bangladesh should avoid brackish shrimp culture. The alternative income generations like crab caging, giant freshwater prawn (Macrobrachium rosenbergii) culture, mixed prawn-rice culture, nypashrimp-crab culture, multi-trophic aquaculture, apiculture, and small entrepreneurship development may be testified to solve employment centric problems. Islam et al. (2004) revealed that agroforestry in the lower saline zone might be a good income generation option.

An integrated Marine Spatial Planning (MSP) in Bangladesh is compelling to achieve various long-term eco-marine growth objectives. Beforehand, a complete inventory of both living and non-living resources 
could be done for the conservation and sustainable use. The multi-disciplinary sustainable marine resource management requires highly professional human resources and motivated researchers. The country should develop a large number of skilled and well-equipped human resources in the field of marine science, marine fisheries, biotechnology, climate change, marine dynamics, marine engineering, ocean acidification, maritime trade, offshore mining, naval architectural engineering, marine geological aspect, marine environment, and ecosystem science, etc. Further research should be carried out on policy analysis, stock assessment, potential resources, ecosystem services, biodiversity conservation, ocean pollution, and climate change.

\section{References}

Ahmed, M.H and Rahman, M.M. (2020), "An assessment of the blue economy opportunities of Bangladesh within the Exclusive Economic Zone (EEZ)", Paper presented at the 7th International Conference on Public Administration and Development, 5-8 February, BPATC, Savar, Dhaka, Bangladesh.

Alam, S., Rahman, M.M. and Arif, A.A. (2021). Challenges and opportunities in artisanal fisheries (Sonadia Island, Bangladesh): The role of legislative, policy and institutional frameworks. Ocean \& Coastal Management, 201, 105424, https://doi.org/10.1016/j.ocecoaman.2020.105424.

Ahmed, N. and Glaser. M. (2016), “Can 'Integrated Multi Trophic Aquaculture' adapt to climate change in Coastal Bangladesh?” Ocean and Coastal Management, Vol.132, pp. 120-131.

Akhtar, A., Bhuiyan, M.A., Mia, M.M., Islam, M.S. and Bhuyan, M.S. (2017), "Livelihood Assessment of Artisanal Fishermen in and Around Chittagong Coastal area of Bangladesh", Social Change, Vol. 7 No. 1 , pp. 97-113.

Akwilapo, F. (2007), "A Comparative Study on Marine Protected Areas between Australia and Tanzania", United Nations, Tokyo.

Alam, M.K. (2014), “Ocean/Blue economy for Bangladesh”, Paper presented at the International Workshop on Blue Economy, Ministry of Foreign Affairs, Dhaka, Bangladesh.

Bdgov (2020), National Web Portal, The Government of the People's Republic of Bangladesh. https://bangladesh.gov.bd/index.php.

Bengtsson, M. (2016), "How to plan and perform a qualitative study using content analysis", Nursing Plus Open, Vol. 2, pp. 8-14. 
Berg, B.L. (2009) Qualitative research methods for the social sciences, 7th ed., Allyn \& Bacon: Boston.

Billah, M.M., Kader, M.A., Siddiqui, A.A.M., Mahmud, S.S. and Khan, M.R. (2018), "Studies on fisheries status and socio-economic condition of fishing community in Bhatiary coastal area Chittagong, Bangladesh", Journal of Entomology and Zoology Studies, Vol. 6 No. 6, pp. 673-679.

Bolton, D., Landells, T. and Roberts, B. (2020), "Sustainable Governance and Responsive Regulation: The Higher Education Sector and Maritime Industry in Australia”, Journal of Sustainability Research, Vol. 2, No. 3, pp. e200023.

Boon, P.J. and Baxter, J.M. (2020), "Putting publication into practice: A summary of the impact of selected articles published in Aquatic Conservation: Marine and Freshwater Ecosystems", Aquatic Conservation: Marine and Freshwater Ecosystems, Vol. 30 No. 9, pp. 1711-1718.

Bray, M.N., Palmer, R., Smith, T.F. and Rist, P. (2019), Old ways for new days: Australian Indigenous peoples and climate change. Local Environment, Vol. 24 No. 5, pp. 473-486.

Cabinet (2020), "Rules of Business 1996 (Revised up to April 2017)", Cabinet Division, Government of the People's Republic of Bangladesh.

Campbell, L.M., Gray, N.J., Fairbanks, L.W., Silver, J.J. and Gruby, R.L. (2013), “Oceans at Rio+20”. Vol. 6 No.6, pp. 439-447.

Dooley, K.J. (2016), "Using manifest content analysis in purchasing and supply management research", Journal of Purchasing and Supply Management, Vol. 22 No. 4, pp. 244-246.

DoF (2017), Fisheries Statistics in Bangladesh: Issues, Challenges and Plans, Department of Fisheries, Dhaka, Bangladesh.

FAO (2014), “Opportunities and Strategies for Ocean and River Resources Management”, Food and Agricultural Organization of the United Nations, Background paper for preparation of the 7th Five Year Plan, Dhaka, Bangladesh.

Giessen, L, Sarker, P.K and Rahman, M.S. (2016), "International and domestic sustainable Forest Management policies: Distributive effects on power among state agencies in Bangladesh", Sustainability,Vol. 8, pp. 335.

Giménez, L, Jolliffe, D and Sharif, I. (2014), "Bangladesh, a Middle-Income Country by 2021: What Will It Take in Terms of Poverty Reduction?", World Bank, Washington DC. 
Hasan, M.M, Hossain, B.H.S Alam, M.J, Chowdhury, K.M.A, Karim, A.A and Chowdhury, N.M.K. (2018), "The Prospects of Blue Economy to Promote Bangladesh into a Middle-Income Country", Open Journal of Marine Science, Vol. 8, pp. 355-369.

Islam, M.M and Shamsuddoha, M. (2018) "Coastal and marine conservation strategy for Bangladesh in the context of achieving blue growth and sustainable development goals (SDGs)", Environmental Science and Policy, Vol. 87, pp. 45-54.

Islam, M.M. (2012), "Poverty in small-scale fishing communities in Bangladesh: context and responses", PhD Thesis, University of Bremen, Germany.

Islam, K.K., Rahman, G.M.M., Uddin, M.N. and Rahman, M.M. (2004) “Performance of Kangkong grown in association with timber saplings", Bangladesh Journal of Crop Science, Vol. 13 No. 15, pp. 77-82.

Krippendorf, K. (2004) Content Analysis: An Introduction to its Methodology, Sage Publications, Beverly Hills, CA.

Millat-e-Mustafa, M. (2002), "A review of forest policy trends in Bangladesh, Bangladesh Policy Trend Report (114-121)".

Mohanty S.K., Dash, P., Gupta, A. and Gaur, P. (2015), "Prospects of Blue Economy in the Indian Ocean", Retrieved from Research and Information System for Developing Countries.

Neuendorf, KA. (2002) The Content Analysis Guidebook, Sage publications.

Rahman MM (2020) Impact of increased salinity on the plant community of the Sundarbans Mangrove of Bangladesh. Community Ecology, 21:273-284, https://doi.org/10.1007/s42974-020-00028-1.

Rahman MM and Akter M (2020) Effectiveness of Village-Based Organization (VBO) in improving the livelihood of the rural community in Bangladesh, Bangladesh Journal of Public Administration (BJPA), 28(2): 27-37. 
Rahman MM, Hossain MR, Islam MN (2021) Climate Change Impact on Sundarbans: Challenges for Mitigation Strategies. In: Jakariya M, Islam MN (eds.) Climate Change in Bangladesh. Springer Climate. Springer, Cham. https://doi.org/10.1007/978-3-030-75825-7_3.

Rahman MM (2021a). The rhetorical blue economy in Bangladesh: Analyzing the inborn regulatory bottlenecks, Acta Aquatica: Aquatic Sciences Journal, 8 (2): 66-73.

https://doi.org/10.29103/aa.v8i2.4775

Rahman MM (2021b) Inbound tourism in Bangladesh: Trend of competitiveness. Bangladesh Journal of Public Administration (BJPA), 29(2) :64-78. http://dx.doi.org/10.36609/bjpa.v29i2.227

Rahman, M.M. (2021c). Assessing the progress and pitfalls of the Ministry of Environment, Forest and Climate Change in achieving SDGs in Bangladesh. Bangladesh Journal of Public Administration (BJPA), 29(2): 140-158. http://dx.doi.org/10.36609/bjpa.v29i2.228

Rahman MM (2021d) Achieving Sustainable Development Goals of Agenda 2030 in Bangladesh: the crossroad of the governance and performance, Public Administration and Policy: An Asia-Pacific Journal 24 (2) 195-211. https://doi.org/10.1108/PAP-12-2020-0056

Rahman MM (2021e) Regulatory Framework of Small-Scale Fishers in Bangladesh: Safeguard or Jeopardy? In: Chuendagdee, R (ed.) Visualizing Small-scale Fisheries of Bangladesh, Too Big To Ignore (TBTI), Canada. http://dx.doi.org/10.2139/ssrn.3939730.

Rahman MM (2021f) Effectiveness of the coastal and marine conservation initiatives in Bangladesh: Analyzing the drawbacks of the legal, policy, and institutional framework. Journal of Indian Ocean Region (forthcoming)

Rahman, MM (2021g) Can ordinary people seek environmental Justice in Bangladesh? Analyzing through the lens of legal, policy, and institutional framework. Bangladesh Journal of Public Administration (BJPA), 29(2): 15-34. DOI:10.36609/bjpa.v29i2.226

Rahman MM (2021h) Biologia Futura: can co-management protect Saint Martin's corals of Bangladesh? BIOLOGIA FUTURA 72, 517-527. https://doi.org/10.1007/s42977-021-00101-4

Rahman MM, Alam MA, Rahman MM, Mamun M and Alam A (2020). Challenges of Artisanal Fishermen: A Case Study from Sonadia Island, Bangladesh. In Alam, M.A., Alam, F. and Begum, D. (Eds.), Knowledge Management, Governance and Sustainable Development: Lessons and Insights from Developing Countries. India: Routledge. https://dx.doi.org/10.2139/ssrn.3773504.

Rahman MM, and Alam MA (2020). Regulatory and Institutional framework for the conservation of coral reefs in Bangladesh: A Critical Review. In Alam MA, Alam F and Begum D (Eds.), Knowledge Management, Governance and Sustainable Development: Lessons and Insights from Developing Countries. India: Routledge, https://dx.doi.org/10.2139/ssrn.3794550. 
Rahman, M.M. and Vacik, H. (2010), "Vegetation analysis and tree population structure of Sal (Shorea robusta) forests: a case study from the Madhupur and Bhawal National Park in Bangladesh", in Polisciano, G. and Farina, O. (Eds.), National Parks: Vegetation, Wildlife and Threats, Nova Science Publishers, New York, USA, pp. 193-206.

Rahman, M.M. (2009), "Plant diversity and anthropogenic disturbances in the Sal (Shorea robusta C.F. Gaertn) forests of Bangladesh", PhD Thesis, University of Natural Resources and Life Sciences, Vienna, Austria.

Rahman, M.M., Nishat, A. and Vacik, H. (2009), "Anthropogenic disturbances and plant diversity of the Madhupur Sal forests (Shorea robusta C.F. Gaertn) of Bangladesh", International Journal of Biodiversity Science and Management, Vol. 5 No. 3, pp. 162-173. https://doi.org/10.1080/17451590903236741.

Sarker, S, Bhuyana, M.A.H, Rahman, M.M, Islam, M.A, Hossain, M.S, Basakc, S.C and Islam, M.M. (2018), "From science to action: Exploring the potentials of Blue Economy for enhancing economic sustainability in Bangladesh", Ocean and Coastal Management, Vol. 157, pp. 180-192.

Shamsuzzaman, M.M and Islam, M.M. (2018), "Analysing the legal framework of marine living resources management in Bangladesh: Towards achieving Sustainable Development Goal 14", Marine Policy, Vol. 87, pp. 255-262.

Shamsuzzaman, M.M., Islam, M.M., Tania, N.J., Al-Mamun, M.A., Barman, P.P. and Xu, X. (2017a), "Fisheries resources of Bangladesh: Present status and future direction", Aquaculture and Fisheries, Vol. 2, pp. 145-156.

Shamsuzzaman, M.M, Xiangmin, X, Islam, M.M, Alam, M.W and Karim, E. (2017b), "Sustainable Marine Fisheries Resources of Bangladesh: A Strategic Response for Economic Security", Indian Journal of Geo Marine Sciences, Vol. 46 No. 4, pp. 757-765.

Spencer, L, Ritchie, J and O'Connor, W. (2003) "Analysis: practices, principles and processes". in J. Ritchie \& J. Lewies (Eds.), Qualitative Research Practice: A Guide for Social Science Students and Researchers, Sage Publications Ltd, London, pp. 199-218.

Yin, M. and Techera, E.J. (2020), "A critical analysis of marine protected area legislation across state and territory jurisdictions in Australia", Marine Policy, Vol. 118, pp. 104019.

\section{Figures}



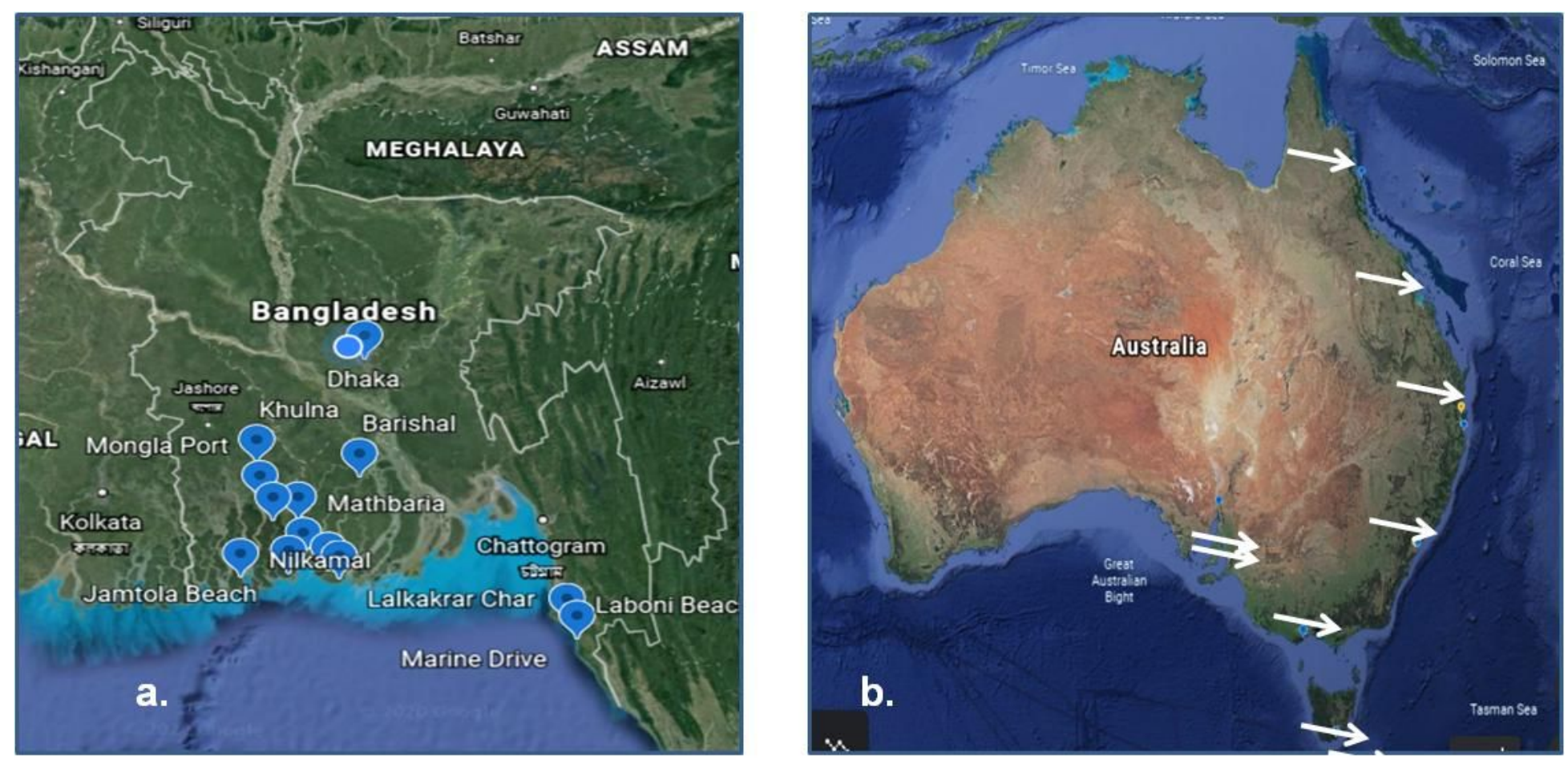

\section{Figure 1}

Google map showing the study areas: a. Bangladesh and b. Australia 


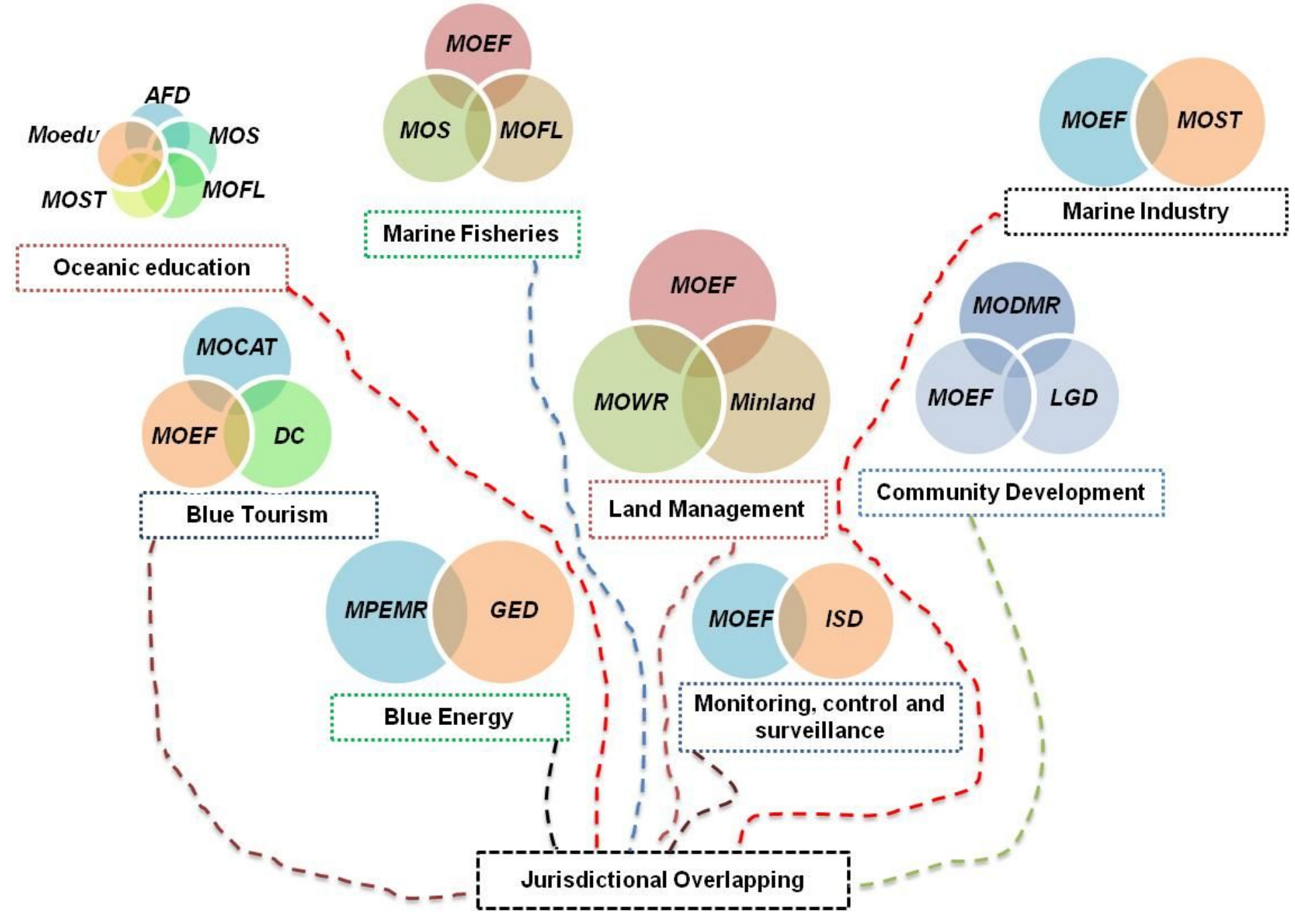

Figure 2

Areas of overlapping jurisdictions in Bangladesh 


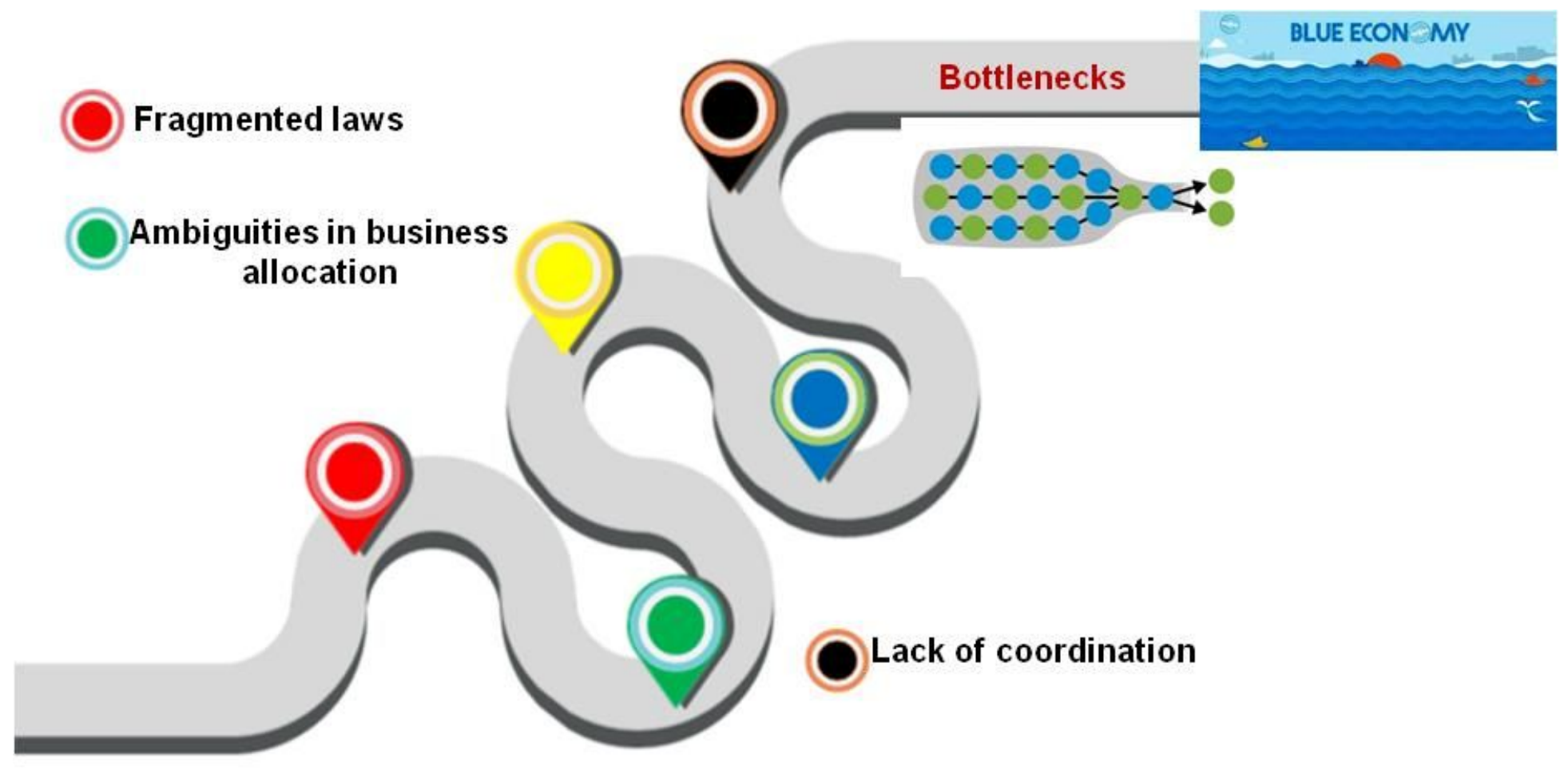

Overlapping jurisdictions

\section{Conflict of interests}

Figure 3

Bottlenecks in the blue economy of Bangladesh 


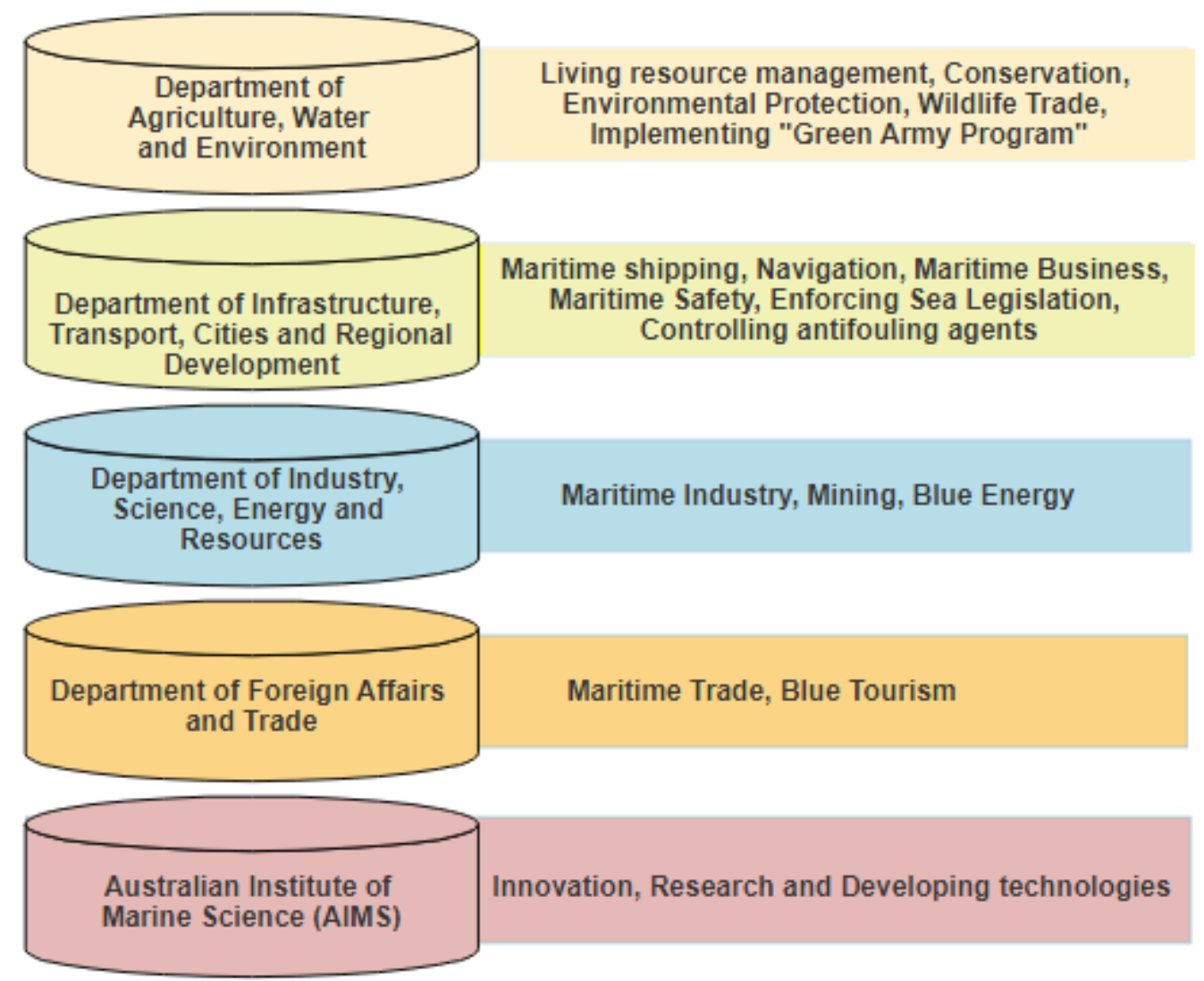

\section{Figure 4}

Mandates of different departments in Australia 


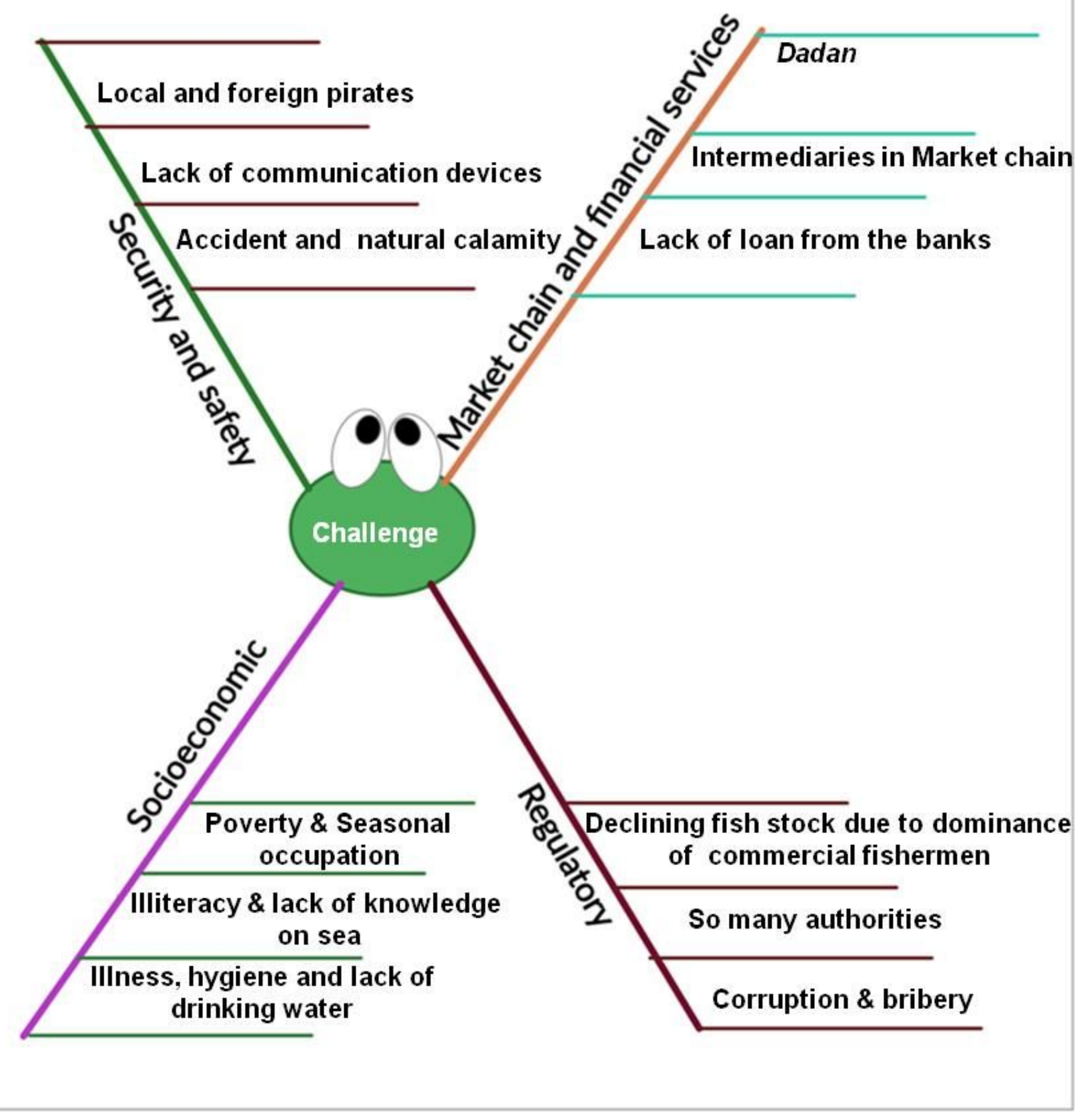

Figure 5

Spider diagram showing the challenges of artisanal and small scale fishers in Bangladesh 


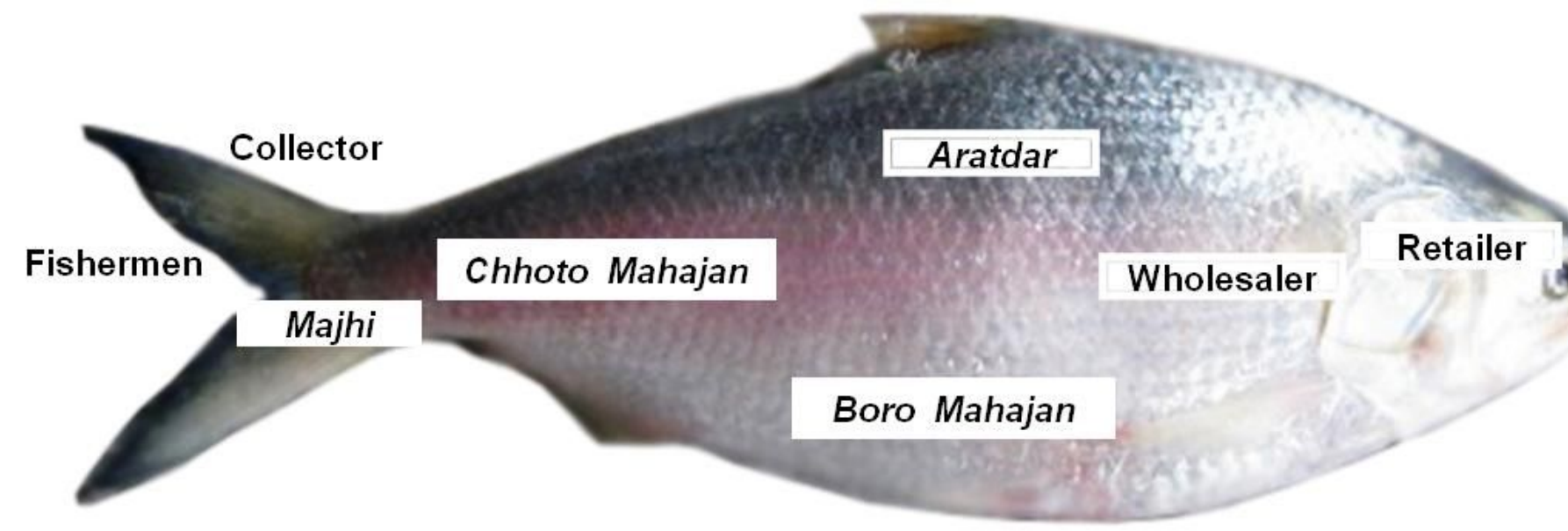

Figure 6

Intermediaries groups in the fish market chain of Bangladesh

\begin{tabular}{l|l|}
\hline M/D & \multicolumn{1}{c|}{ Reallocation of business } \\
\hline MOFL & Marine and coastal fisheries including protected areas, mariculture, pearl culture, brackish shrimp culture \\
\hline MOEF & Terrestrial forest resources, tackling climate change, the focal point of land-based pollutions \\
\hline MOS & Sea ports, maritime shipping, navigation, rescue \& safety, enforcement of sea laws, marine-based pollution \\
\hline Moind & Marine industries including shipyard, ship recycling, marine optical fiber and tourism \\
\hline Mincom & Marine trade and commerce \\
\hline MPEMR & Exploration and mining for minerals, blue energy \\
\hline Moedu & Training, education and research \\
\hline MOST & Biotechnology, sea weeds, the focal point of oceanographic science \\
\hline MOFA & The focal point of high sea governance \\
\hline LGD & The focal point of local governance \\
\hline ISD & The focal point of monitoring, control and surveillance \\
\hline
\end{tabular}

Figure 7

Proposed business reallocation for key ministries/divisions of Bangladesh 